\title{
Pengaruh Komitmen Profesi dan Self-Efficacy Terhadap Konflik Peran
}

\author{
Pipih Sopiyan \& Haris Abdul Aziz \\ Program Studi Manajemen FEB Universitas Majalengka \\ e-mail: pipihoke@gmail.com
}

\begin{abstract}
ABSTRAK
Penelitian ini dilakukan pada karyawan Perumda Bank Perkreditan Rakyat (BPR) Pusat Majalengka. Tujuan penelitian ini adalah untuk mengetahui bagaimana pengaruh komitmen profesi dan Self-efficacy terhadap konflik peran pada karyawan Perumda BPR Pusat Majalengka baik secara parsial maupun simultan. Penelitian ini menggunakan metode survei dengan pendekatan analisis deskriptif dan verifikatif. Populasi dalam penelitian ini adalah seluruh karyawan Perumda BPR Pusat Majalengka sebanyak 47 responden, Diman hasil penelitian menunjukan bahwa komitmen profesi, self-efficacy pada karyawan Perumda BPR Pusat Majalengka berada dalam kategori sangat tinggi. sedangkan konflik peran berada dalam kategori sangat baik. Secara parsial komitmen profesi tidak berpengaruh secara signifikan terhadap konflik peran dan self-efficacy berpengaruh positif signifikan terhadap konflik peran. Secara simultan komitmen profesi dan self-efficacy berpengaruh positif dan signifikan terhadap konflik peran.
\end{abstract}

Kata Kunci : Komitmen Profesi, Self-efficacy

\section{ABSTRACT}

This research was carried out on employees of the Regional Office of the Rural Bank of Majalengka. The purpose of this study was to find out how the influence of professional commitment and Self-efficacy on role conflict in employees of the Regional Public Housing Agency of the Central Majalengka both partially and simultaneously. This study uses a survey method with a descriptive and verification analysis approach. The populations in this study were all employees of the Majalengka BPR Regional Regulation Office as many as 47 respondents.The results of the study show that professional commitment, self-efficacy on employees of the BPR Perumda Majalengka Center are in a very high category. While role conflict is in a very good category. Partially profession commitment does not significantly influence role conflict and self-efficacy has a significant positive effect on role conflict. Simultaneously professional commitment and self-efficacy have a positive and significant effect on role conflict.

Keywords: Professional Commitment, Self-Efficacy

\section{PENDAHULUAN}

\section{Latar Belakang}

Manusia sebagai sumber tenaga kerja merupakan salah satu asset perusahaan yang mempunyai peranan penting dalam kegiatan perusahaan. Persaingan usaha yang ketat menuntut sumber daya manusia terbaik dan profesional sehingga sumber daya manusia senantiasa menempati kedudukan yang semakin penting dalam perusahaan (Veithzl Rivai dan Eva J. ${ }^{16)}$, 2009:15).

Keterlibatan tenaga profesional pada organisasi akan menimbulkan sebuah kondisi dimana individu mengalami dilema yang disebut dengan konflik peran. Konflik peran timbul karena adanya dua perintah yang berbeda yang diterima secara bersamaan dan pelaksanaan salah satu perintah saja akan mengakibatkan terabaikannya perintah yang lain. Konflik peran lebih bersifat psikologis, Greenhaus dan Beutell (1985) dalam Uswatun Chasanah $^{14)}$ (2016:45) menjelaskan sumber-sumber penyebab konflik peran diantaranya semakin banyak waktu untuk bekerja maka semakin sedikit waktu untuk keluarga termasuk waktu untuk berkomunikasi, stres yang dimulai dalam satu peran yang terjatuh ke dalam peran lain, kecemasan dan kelelahan yang disebabkan ketegangan dari satu peran dapat mempersulit untuk peran yang lainnya.

Setiap individu pasti pernah mengalami konflk peran pada kehidupannya, baik itu pada tingkat ringan, sedang atau tinggi. Konflik peran muncul apabila inidividu mengalami kesulitan dalam menyesuaikan kedua peran, dalam hal ini perannya sebagai seorang makhluk sosial dimana individu memerlukan interaksi sosial dengan keluarga dan temannya diluar lingkungan perusahaan/organisasi dan perannya sebagai anggota dari sebuah perusahaan yang harus bertanggung jawab pada profesi atau pekerjaannya.

Setiap individu dituntun memiliki komitmen profesi yang baik. Komitmen merupakan salah satu 
unsur penting dalam dunia kerja saat ini karena komitmen bisa mempengaruhi keberhasilan dan kinerja seseorang dalam pekerjaannya. Dengan adanya komitmen yang tinggi, seorang karyawan akan mencintai pekerjaannya dan mampu bekerja dengan rasa penuh tanggung jawab. Berbeda dengan karyawan yang memiliki komitmen rendah terhadap profesinya. Komitmen yang tinggi akan memacu karyawan bekerja sebaik mungkin sehingga produktivitas dapat meningkat dan tujuan organisasi dapat tercapai. Maka dari itu komitmen profesi yang tinggi sangat penting bagi suatu organisasi untuk pencapaian tujuan yang sesuai dengan yang diharapkan.

Seperti yang dijelaskan diawal, keterlibatan tenaga profesional pada organisasi akan menimbulkan konflik peran. Koflik peran dapat ditekan atau dikendalikan diantaranya oleh selfefficacy. Menurut Alwisol ${ }^{1)}$, 2014:287) self-efficacy adalah penilaian diri, apakah dapat melakukan tindakan yang baik atau buruk, tepat atau salah, bisa atau tidak bisa mengerjakan sesuai yang diisyaratkan. Menurut Lee dan Bobko (1994) dalam Engko ${ }^{5)}$, 2008:34) menyatakan bahwa individu yang memiliki self-efficacy tinggi akan mencurahkan seluruh usaha dan perhatian untuk mencapai tujuannya dan apabila terjadi kegagalan akan membuatnya berusaha lebih giat lagi. Seseorang yang memiliki self-efficacy yang tinggi mereka mampu melakukan sesuatu untuk mengubah kejadian-kejadian disekitarnya, sedangkan seseorang dengan self-efficacy yang rendah menganggap dirinya pada dasarnya tidak mampu mengerjakan segala sesuatu yang ada disekitarnya. Dalam situasi sulit, orang yang memiliki self-efficacy yang rendah cenderung mudah menyerah, sementara orang yang memiliki self-efficacy yang tinggi akan berusaha lebih keras lagi untuk mengatasi tantangan yang ada.

Self-efficacy sangat diperlukan dalam mengembangkan kinerja karyawan karena dengan adanya self-efficacy dalam diri individu. Menurut Saks (1994) dalam Dea Handrika dan Made Gede (2017:879) individu yang mempunyai self-efficacy tinggi akan mengerjakan tugas dengan mempertimbangkan konsekuensi kesalahan, sebaliknya individu dengan self-efficacy rendah akan merasa mendapat tekanan atau stres pada pekerjaannya. Apabila individu dengan self-efficacy tinggi mengalami tekanan pada pekerjaan, hal tersebut merupakan tantangan dan kesempatan mereka untuk menunjukkan keahliannya. Individu yang memperhatikan self-efficay akan mampu untuk menentukan minat dan pilihan pada pekerjaan.

Karyawan Perumda BPR Pusat Majalengka merupakan sumber daya manusia yang erat kaitannya dengan professionalism, dimana para karyawan dituntut memiliki komitmen profesi dan self-efficacy yang tinggi. Perumda BPR Majalengka merupakan salah satu BUMD milik Kabupaten Majalengka yang beroperasi pada bidang perbankan. Perumda BPR Majalengka mempunyai peran strategis dalam menciptakan pertumbuhan ekonomi di wilayah Majalengka, selain itu juga Perumda BPR Majalengka memberikan lapangan pekerjaan serta memberikan kontribusi pada pendapatan asli daerah. Visi dari Perumda BPR Majalengka adalah memujudkan Perusahaan Daerah Bank Perkreditan Rakyat Majalengka yang terbaik dan terpercaya. Dalam mewujudkan visi tersebut maka karyawan Perumda BPR Pusat Majalengka dituntut memiliki komitmen profesi dan self-efficacy yang tinggi. Berdasarkan data yang diperoleh pada tahun 2017 bahwa rata-rata tingkat kehadiran karyawan mencapai 97\%. Selain itu komitmen pofesi karyawan Perumda BPR Pusat Majalengka terlihat pada saat kebersediaan karyawan untuk bekerja lembur dalam menyelesaikan pekerjaannya, selalu bersikap ramah dan menjaga sopan santun ketika berhadapan dengan nasabah, hal ini menunjukan karyawan Perumda BPR Pusat Majalengka menjaga komitmen profesi dalam bekerja. Akan tetapi pada hakikatnya karyawan Perumda BPR Pusat Majalengka seperti manusia pada umumnya, mereka adalah makhluk sosial. Dalam diri mereka terdapat hasrat untuk berkomunikasi, bergaul, berkumpul dan berinterakasi dengan orang lain (diluar lingkungan perusahaan). Mereka memiliki kebutuhan akan rasa memiliki dan rasa kasih sayang (social need). Bentuk pemenuhan dari kebutuhan ini seperti berkumpul bersama teman, keluarga dan sahabat, serta pergi berwisata bersama.

Rutinitas yang padat yang berulang hampir setiap hari memaksa karyawan Perumda BPR Pusat Majalengka hanya memiliki sedikit waktu untuk berkumpul, bersosialisasi dan berinteraksi dengan keluarga, teman dan sahabat. Selain itu ada sekali waktu karyawan berada pada keadaan suasana hati yang buruk. Keadaan seperti itu terjadi dimana suasana hati atau pikiran terpengaruh oleh hal-hal yang mengganggu sehingga individu itu ingin menyendiri untuk menenangkan hati serta pikirannya. Individu yang sedang dalam keadaan suasana hati yang buruk cenderung bersikap tak acuh, lebih banyak diam, tidak ada senyum diwajahnya dan mudah marah. Namun kondisi suasana hati yang buruk seperti yang dijelaskan sebelumnya harus bisa diatasi oleh para karyawan terutama dibagian pelayanan. Karyawan harus selalu bersikap ramah, mudah senyum dan memberikan pelayanan yang terbaik kepada nasabah.

Kondisi seperti yang dijelaskan di atas menyebabkan timbulnya konflik peran pada karyawan Perumda BPR Pusat Majalengka. Disatu sisi karyawan Perumda BPR Pusat Majalengka harus melaksanakan tuntutan pekerjaan dengan menunjukan komitmen profesi mereka, akan tetapi 
disisi lain mereka harus memenuhi tuntutan kebutuhan sebagai makhluk sosial.

Dari uraian yang dijelaskan diatas, penulis melihat bahwa konflik peran yang dialami oleh karyawan Perumda BPR Pusat Majalengka tentunya perlu dikendalikan dengan baik.

\section{Rumusan Masalah}

Berdasarkan latar belakang yang diuraikan, maka rumusan masalah sebagai berikut:

1. Bagaimana pengaruh komitmen profesi terhadap konflik peran di Perumda BPR Pusat Majalengka.

2. Bagaimana pengaruh self-efficacy terhadap konflik peran di Perumda BPR Pusat Majalengka.

3. Bagaimana pengaruh komitmen profesi dan selfefficacy terhadap konflik peran di Perumda BPR Pusat Majalengka.

\section{Tujuan Penelitian}

Adapun tujuan dari penelitian ini adalah Untuk mengetahui bagaimana pengaruh komitmen profesi terhadap konflik peran di Perumda BPR Pusat Majalengka; serta bagaimana pengaruh self-efficacy terhadap konflik peran di Perumda BPR Pusat Majalengka.

1. Untuk mengetahui bagaimana komitmen profesi dan self-efficacy terhadap konflik peran di Perumda BPR Pusat Majalengka.

\section{TINJAUAN PUSTAKA}

\section{Komitmen Profesi}

Menurut Mowday, et al. (1979) dalam Rahayu (2005:19) komitmen profesional dapat didefinisikan sebagai berikut professional commitment can be described as the intensity of an individual's identification with, and level of involvement in his or her profession- komitmen profesi dapat didefiniskan sebagai intensitas identifikasi individu dan tingkat keterlibatan dalam profesinya.

Konsep komitmen profesi menurut Hall (1968) dalam Kalbers dan Forgaty (1995) dalam Siti Noor (2005:143) yakni hubungan dengan sesama profesi (community affiliation), kebutuhan untuk mandiri (autonomy demand), keyakinan terhadap peraturan sendiri atau profesi (belief self regulation) Dedikasi pada profesi (dedication), kewajiban sosial (social obligation). Menurut Aranya et al. (1984) dalam Intiyas, dkk (2007:12) indikator untuk mengetahui tingkat komitmen profesi pada seseorang dapat terlihat dari tanggung jawab profesi, keaktifan dalam bekerja, pengorbanan Waktu dan sikap loyal.

\section{Self Efficacy}

Bandura dan Bailey (1990) dalam Greenberg dan Baron $^{2)}$, 2003:12) menyebutkan bahwa selfeficacy adalah keyakinan seseorang terhadap kemampuan dirinya melakukan sesuatu atau pekerjaan yang spesifik yang menjadi tanggung jawabnya.

\section{Konflik Peran}

Konflik peran menurut Kun Maryati (2007:23) adalah kejadian yang simultan dari dua tekanan atau lebih seperti ketaatan pada satu hal akan membuat sulit atau tidak mungkin mentaati yang lainnya.. Konflik peran terjadi ketika ada berbagai tuntutan dari banyak sumber yang menyebabkan karyawan menjadi kesulitan dalam menentukan tuntutan apa yang harus dipenuhi tanpa membuat tuntutan lain diabaikan. Dimensi yang digunakan dalam penelitian ini menurut Stoner, et al. (1990) dalam Sunyoto ${ }^{14)}$ (2012:73) adalah; Time Pressure; Family size and support; Kepuasan kerja dan Size of firm

\section{Hubungan antara Komitmen Profesi dengan Konflik Peran}

Menurut Aranya et. al. (1984) dalam Intiyas dkk. (2007: 14) berpendapat bahwa komitmen profesi merupakan kekuatan relatif terhadap keterlibatan individu dalam profesi tertentu, kemauan untuk mengerahkan usaha atas nama profesi serta keinginan untuk mempertahankan keanggotaan didalamnya. Tingginya komitmen profesi pada karyawan tidak hanya memberikan dampak positif bagi dirinya. Namun terdapat pula dampak yang tidak diharapkan pada karyawan seperti terjadinya konflik peran. Menurut Stoner et. al. dalam Sunyoto ${ }^{14)}$ (2012:65) merupakan suatu gejala psikologis yang dialami oleh karyawan yang bisa menimbulkan ketidaknyamanan dalam bekerja dan berpotensi menurunkan motivasi kerja. Konflik peran berdampak negatif terhadap perilaku karyawan, seperti timbulnya ketegangan kerja, penurunan komitmen pada organisasi dan penurunan kinerja secara keseluruhan. Konflik peran terjadi ketika ada berbagai tuntutan dari banyak sumber yang menyebabkan karyawan menjadi kesulitan dalam menentukan tuntutan apa yang harus dipenuhi tanpa membuat tuntutan lain diabaikan.

\section{Hubungan antara Self-efficacy dengan Konflik Peran}

Menurut Bandura (1986) dalam Noora Noormania (2014:40) self-efficacy adalah keyakinan mengenai kemampuan seseorang untuk menggerakan motivasi, sumber kesadaran dan serangkaian tindakan yang dibutuhkan untuk menghadapi situasi yang menuntut. kemudian menurut Alwisol (2014:287) Self-efficacy adalah penilaian diri, apakah individu dapat melakukan tindakan yang baik atau buruk, tepat atau salah, bisa atau tidak bisa untuk mengerjakan sesuatu dengan yang dipersyaratkan. Konflik peran bagi sebagian orang dianggap sebagai sebuah ancaman, namun hal itu berbeda dengan individu yang memiliki self-efficacy tinggi.. Sedangkan. Individu dengan self eficacy tinggi akan 
menganggap konflik peran sebagai sebuah tantangan bukan sebagai sebuah ancaman. Kondisi tersebut diharapkan dapat mengendalikan dan meminimalisir konflik peran.

\section{Kerangka Pemikiran}

Manusia sebagai sumber tenaga kerja yang merupakan asset dalam perusahaan. Pemeliharaan karyawan bertujuan untuk memelihara atau meningkatkan kondisi fisik, mental dan meminimalisir segala sesuatu yang bisa menyebabkan menurunnya kinerja karyawan salah satunya adalah konflik peran. Konflik peran menurut Stoner, et. al. dalam Sunyoto $^{14)}$, 2012:65) merupakan suatu gejala psikologis yang dialami oleh karyawan yang bisa menimbulkan ketidaknyamanan dalam bekerja dan berpotensi menurunkan motivasi kerja. Konflik peran terjadi ketika dua atau lebih tuntutan terjadi secara bersamaan dan saling bertentangan satu dengan yang lain sehingga menyebabkan kesulitan pada karyawan. Semakin banyak waktu yang digunakan untuk bekerja maka semakin sedikit waktu untuk keluarga. Semakin banyak anggota keluarga maka semakin banyak konflik dan semakin banyak dukungan keluarga maka semakin sedikit konflik. Semakin tinggi kepuasan kerja maka konflik yang dirasakan semakin sedikit dan sebaliknya semakin rendah kepuasan kerja maka konflik yang dirasakan tinggi. Banyaknya pegawai dalam instansi mungkin mempengaruhi konflik kerja seseorang.

Komitmen profesi merupakan kekuatan relatif terhadap keterlibatan individu dalam profesi tertentu, kemauan untuk mengerahkan usaha atas nama profesi serta keinginan untuk mempertahankan keanggotaan didalamnya. Komitmen profesi tinggi harus dimiliki oleh setiap karyawan, karena dengan komitmen pofesi yang tinggi maka kinerja karyawan pun akan baik, jika kinerja karyawan baik maka tujua perusahaan akan cepat terealisasi.

Selain komitmen profesi, konflik peran juga dipengaruhi oleh self efficacy. Menurut Bandura (1986) dalam Noora Noormania $\left.{ }^{10)}, 2014: 40\right)$ selfefficacy adalah keyakinan mengenai kemampuan seseorang untuk menggerakan motivasi, sumber kesadaran dan serangkaian tindakan yang dibutuhkan untuk menghadapi situasi yang menuntut. Individu dengan efikasi diri tinggi akan mempunyai mempunyai semangat dan ketekunan yang lebih kuat dalam mengatasi masalah konflik peran yang dihadapinya, serta mampu memobilisasi energi yang lebih besar dalam menghadapi masalah tersebut, dimana hal ini sangat diperlukan di dalam organisasi dan menentukan kepuasan kerja. Sebaliknya, individu dengan efikasi diri rendah mudah menyerah dan putus asa bila menghadapi kesulitan dan permasalahan.

Dari uraian di atas dapat dilihat bahwa komitmen profesi dan self-efficacy memberikan pengaruh kepada konflik peran yang terjadi pada karyawan. Konflik peran harus diminimalisir dan dikendalikan agar tujuan perusahaan dapat tercapai.

\section{Hipotesis}

Berdasarkan kajian pustaka dan kerangka pemikiran di atas, maka dirumuskan hipotesis sebagai berikut : $\mathrm{H}_{1}$ : Komitmen profesi berpengaruh signifikan terhadap konflik peran.

$\mathrm{H}_{2}$ : Self-efficacy berpengaruh signifikan terhadap konflik peran.

$\mathrm{H}_{3}$ : Komitmen profesi dan self-efficacy berpengaruh signifikan terhadap konflik peran.

\section{METODE PENELITIAN}

Metode yang digunakan dalam penelitian ini adalah metode survei dengan pendekatan analisis deskriptif dan analisis verifikatif. Populasi dalam penelitian adalah karyawan Perumda BPR Pusat Majalengka yang berjumlah 47 orang.

Jenis data yang digunakan dalam penelitian ini yaitu data kualitatif yang dikuantitatifkan. Sumber data diperoleh dari data primer dimana data yang diambil secara langsung dari responden yaitu melalui pengisian kuesioner. Kuesioner yang disebarkan kepada karyawan Perumda BPR Majalengka berupa pernyataan (4 pernyataan untuk komitmen profesi, 8 pernyataan mengenai self-efficacy dan 12 pernyataan untuk konflik peran). Cara menilai jawaban dari setiap kuesioner melalui sikap responden dengan skala skala likert. Pengujian instrumen penelitian dilakukan dengan Uji Validitas dan Reliabilitas. Selanjutnya dilakukan konversi dari data berskala ordinal ke data berskala interval dengan Method of Successive Interval(MSI) kemudian dilakukan Uji Normalitas Data. Analisis data yang digunakan melalui Analisis Regeresi Berganda, koefisien Determinasi, Uji t dan Uji f.

\section{HASIL DAN PEMBAHASAN}

\section{Komitmen Profesi Pada Karyawan Perumda BPR Pusat Majalengka}

Berdasarkan tanggapan responden terhadap 4 item pernyataan mengenai komitmen profesi diperoleh skor 815 yang berada pada interval 783-938 menujukkan bahwa komitmen profesi pada karyawan Perumda BPR Pusat Majalengka berada dalam kategori sangat tinggi. Komitmen profesi karyawan Perumda BPR Pusat Majalengka terlihat dari beberapa hal yakni dalam bekerja karyawan Perumda BPR Pusat Majalengka selalu menggunakan pertimbangan moral dan profesional, mereka selalu terlibat aktif dalam kegiatan yang diadakan perusahaan, mereka sadar akan waktu yang dikorbankan untuk pekerjaan dan mereka senantiasa mendahulukan kepentingan profesi dibanding dengan kepentingan lain. 


\section{Self-efficacy Pada Karyawan Perumda BPR Pusat Majalengka}

Berdasarkan tanggapan responden terhadap 8 item pernyataan mengenai self-efficacy yang terdiri dari 8 indikator diperoleh skor 1.644 yang berada pada interval 1.581-1.880 menujukkan bahwa selfefficacy pada karyawan Perumda BPR Pusat Majalengka berada dalam kategori sangat tinggi. Tingginya self-efficacy pada karyawan Perumda BPR Pusat Majalengka terlihat dari keyakinan atau rasa percaya diri dari karyawan Perumda BPR Pusat Majalengka dalam menyelesaikan tugas yang diberikan perusahaan dengan baik walaupun tugas tersebut tergolong sulit dan menantang selain itu Saya yakin dapat mencapai target yang diberikan perusahaan. Selain itu rasa optimis dari karyawan Perumda BPR Pusat Majalengka dalam mencapai target yang diberikan perusahaan juga semakin memperlihatkan tingginya self-efficacy pada karyawan Perumda BPR Pusat Majalengka.

\section{Konflik Peran Pada Karyawan Perumda BPR Pusat Majalengka}

Berdasarkan tanggapan responden terhadap 12 item pernyataan mengenai konflik peran yang terdiri dari 12 indikator diperoleh skor 2.469 yang berada pada interval 2.369-2.820 yang menujukkan bahwa tingkat pengelolaan terhadap konflik peran karyawan Perumda BPR Pusat Majalengka berada dalam kategori sangat baik. Hal ini terwujud dalam ketepatan mereka menyelesai tugas sehingga mereka mempunyai cukup waktu bersama keluarga teman maupun masyarakat, disamping itu dukungan penuh dirasakan oleh karyawan dari keluarga.

Tabel 1.

Analisis Regresi Berganda

Coefficients $\mathrm{a}^{\mathrm{a}}$

\begin{tabular}{|c|c|c|c|c|c|c|c|c|}
\hline \multirow{2}{*}{ Model } & \multicolumn{2}{|c|}{$\begin{array}{l}\text { Unstandardized } \\
\text { Coefficients }\end{array}$} & \multirow{2}{*}{$\begin{array}{c}\begin{array}{c}\text { Standardized } \\
\text { Coefficients }\end{array} \\
\text { Beta }\end{array}$} & \multirow{2}{*}{$\mathrm{t}$} & \multirow{2}{*}{ Sig. } & \multicolumn{3}{|c|}{ Correlations } \\
\hline & B & Std. Error & & & & $\begin{array}{l}\text { Zero- } \\
\text { order }\end{array}$ & Partial & Part \\
\hline (Constant) & 4,769 & 5,268 & & ,905 & ,370 & & & \\
\hline Komitmen_profesi &, 072 &, 081 & ,072 & ,891 & ,378 & ,220 & ,133 & ,071 \\
\hline Self_Eficacy & ,832 & 081 & ,832 &, 260 &, 000 & ,845 & ,840 & ,819 \\
\hline
\end{tabular}

Berdasarkan tabel 1, diketahui bahwa didapat persamaan regresi sebagai berikut :

$$
Y=4,769+0,072 X_{1}+0,832 X_{2}
$$

Hasil penelitian berdasarkan tabel 1. di atas menunjukan bahwa variabel komitmen profesi merupakan variabel yang tidak dominan dengan tingkat kontribusi sebesar $4,48 \%$ dan tidak berpengaruh secara signifikan terhadap konflik peran. Artinya konflik peran pada karyawan Perumda BPR Pusat Majalengka tidak dipengaruhi secara signifikan oleh komitmen profesi.

Hasil penelitian menunjukan bahwa variabel self-efficacy merupakan variabel yang dominan dengan tingkat kontribusi sebesar $71,4 \%$ dan hasilnya berpengaruh positif dan signifikan terhadap konflik peran. Artinya jika karyawan Perumda BPR Pusat Majalengka mempunyai self-efficacy yang tinggi maka tingkat pengelolaan konflik peran akan semakin baik.

Pengaruh Komitmen Profesi Dan Self-efficacy

Terhadap Konflik Peran Pada Karyawan Perumda BPR Pusat Majalengka
Tabel 2.

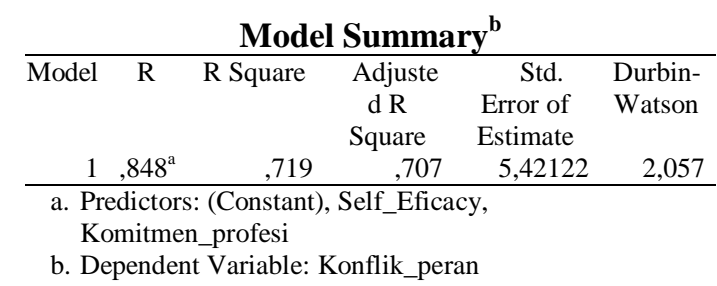

Tabel 3.

ANOVA $^{\mathrm{a}}$

\begin{tabular}{llrrrr}
\hline Model & $\begin{array}{l}\text { Sum of } \\
\text { Squares }\end{array}$ & df & $\begin{array}{c}\text { Mean } \\
\text { Square }\end{array}$ & F & Sig. \\
\hline Regression & 3316,805 & 2 & 1658,403 & 56,428 &, $000^{\mathrm{b}}$ \\
Residual & 1293,144 & 44 & 29,390 & & \\
Total & 4609,949 & 46 & & & \\
\hline
\end{tabular}

a. Dependent Variable: Konflik_peran

b. Predictors: (Constant), Self_Eficacy, Komitmen_profesi

Berdasarkan tabel 2. dan 3. di atas diketahui bahwa secara simultan variabel komitmen profesi dan self-efficacy berpengaruh positif dan signifikan terhadap konflik peran dengan tingkat kontribusi sebesar 71,9 \%. Artinya jika karyawan mampu 
meningkatkan komitmen dan self efficacy, maka tingkat pengelolaan konflik peran akan semakin baik.

\section{KESIMPULAN DAN SARAN}

\section{Kesimpulan}

1. Komitmen profesi tidak berpengaruh signifikan terhadap konflik peran. Artinnya bahwa tinggi rendahnya konflik peran pada karyawan Perumda BPR Pusat Majalengka lebih ditentukan oleh variabel lain selain komitmen profesi.

2. Self-efficacy berpengaruh positif dan signifikan terhadap konflik peran. Artinnya bahwa tinggi rendahnya konflik peran pada karyawan Perumda BPR Pusat Majalengka ditentukan oleh tinggi rendahnya self efficacy. Semakin tinggi self-efficacy maka pengelolaan konflik peran pun akan semakin baik.

3. Komitmen profesi dan self-efficacy berpengaruh positif dan signifikan terhadap konflik peran. Artinya jika komitmen profesi dan self-efficacy meningkat maka tingkat pengelolaan konflik peran akan semakin baik.

\section{Saran}

1. Memaksimalkan waktu bekerja dengan membuat daftar prioritas pekerjaan./daftar tugas yang harus segera dikerjakan agar penyelesaiannya lebih terencana dan tepat waktu. Sehingga waktu istirahat benar-benar untuk mengistirahatkan badan dan pikiran.

2. Motivasi dan apresiasi terhadap karyawan senantiasa secara rutin dilakukan untuk meningkatkan rasa percaya diri pada karyawan

Dukungan moril dari keluarga, teman serta lingkungan akan memberikan keleluasan terhadap karyawan dalam meningkatkan komitmen profesi dan self efficacy, sehingga tingkat pengelolaan konflik peran semakin baik.

\section{DAFTAR PUSTAKA}

Alwisol. 2014. Psikologi Kepribadian Edisi Revisi. UMM Press. Malang.

Baron, R. A \& Greenberg, J. 2003. Behavior in Organization: Understanding and Managing The Human Side of Work. Allyn And Bacon. New York.

Cahyono D. \& Ghozali, I. (2002). Pengaruh Jabatan, Budaya Organisasi Dan Konflik Peran Terhadap Hubungan Kepuasan Kerja Dengan Komitmen Organisasi: Studi Empiris Di Kantor Akuntan Publik. Jurnal Riset Akuntansi Indonesia. Vol 5 No. 3, Hal.341-361.

Dea Handrika dan Made Gede Wirakusuma, 2017, Pengaruh Partisipasi Penyusunan Anggaran
Pada Kinerja Manajerial yang Dimoderasi Selfefficacy dan Motivasi Kerja, E-Jurnal Akuntansi, Vol 20, No 2, 875-903.

Engko, Cecilia. 2008. Pengaruh Kepuasan Kerja Terhadap Kinerja Individual Dengan Self Esteem Dan Self-efficacy Sebagai Variabel Intervening. Makalah Simposium Nasional Akuntansi IX di Universitas Andalas Padang.

F. Budi Hardiman. 2016. Filsafat Untuk Para Professional. PT Media Kompas Nusantara. Jakarta.

Intiyas, dkk. 2007. Situasi Akuntan Publik Dari Aspek Keprilakuan, The $1^{\text {st }}$ Accounting Conference, Fakultas Ekonomi Universitas Indonesia.

I Wayan Murdana Yasa. 2017. Pengaruh Konflik Peran Dan Ambiguitas Peran Terhadap Kinerja Pegawai Melalui Mediasi Stres Kerja Pada Dinas Kesehatan Kota Denpasar Bali. Jurnal Ekonomi \& Bisnis, Vol. 4, No 1. Maret 2017, Hal 38-57.

Kun Maryati Dan Juju Suryawati. 2007. Sosiologi Untuk SMA Dan MA Kelas X. PT Penerbit Erlangga. Jakarta.

Noora Noormania. 2013. Pengaruh Self-efficacy Dan Iklim Organisasi Terhadap Kinerja Karyawan.(Studi pada PT Wijaya Karya Beton Tbk.), Skripsi Universitas Syarif Hidayatullah Jakarta.

Nurika Restuningdiah. 2009. Pengaruh Komitmen Profesional Terhadap Kepuasan Kerja Akuntan. Jurnal Ekonomi Bisnis. Vol 4, No. 3, Nopember 2009. Hal 251-258.

Rahayu, Sri Diah Dan Faisal. 2005. Pengaruh Komitmen Terhadap Respon Auditor Atas Tekanan Sosial. Jurnal Akuntansi Dan Auditing Indonesia Vol. 9, No. 1, Juni 2005. Fe Uii Yogyakarta.

Siti Noor Khikmah. 2005. Pengaruh Profesionalisme Terhadap Keinginan Berpindah Dengan Komitmen Organisasi Dan Kepuasan Kerja Sebagai Variabel Intervening. Jurnal Maksi Vol. 5, No. 2, Agustus 2005.

Sunyoto, D. 2012. Mengelola Konfli Dalam Upaya Meningkatkan Kinerja Organisasi. Javanisi. Yogyakarta.

Uswatun Chasanah. 2016. Hubungan Antara Konflik Peran Ganda Dengan Kepuasan Pernikahan Pada Pekerja Perempuan Di Departement Weafing 2 Pt. Daya Manunggal Salatiga. Skripsi Fakultas Psikologi Universitas Kristen Satya Wacana Salatiga. 